\title{
Indigenous use of plants in south-eastern Australia
}

\author{
Beth Gott
}

Honorary Research Fellow, School of Biological Sciences, Monash University

\begin{abstract}
The removal of Indigenous people from their traditional lands in south-eastern Australia has rendered it necessary to collect much of the information about plant use from nineteenth century sources. Despite these difficulties, a fully referenced database of species occurring in Victoria which have known Indigenous use in some part of Australia contains over one thousand entries, approximately one third of the total native flora in the state. Databases have been assembled also for New South Wales, Tasmania and the higher rainfall areas of South Australia. They contain plants used for food, medicines, fibre, implements, adhesives and cultural purposes.

Underground storage organs constituted the major food source in higher rainfall areas, whereas seeds become more important in the arid lands. Microseris lanceolata (Walp.) Sch. Bip., and Microseris scapigera (Forst.) Sch.Bip., Murnong or Yam Daisy, widely used for food, present an interesting taxonomic and biogeographic study.
\end{abstract}

\section{Introduction}

Aborigines populated the south-eastern parts of the Australian continent at least 40,000 years before present. They depended on the use of the native flora and fauna for all of life's necessities, and their continued survival in Australia is evidence that they achieved a balance between exploitation and renewal of the resources. Since fire was regularly applied to significant parts of the landscape, there is no doubt that many of the patterns of biodiversity encountered by the European invaders were of Aboriginal creation. In setting high biodiversity as a goal of present-day management, this is not always acknowledged. (Gott 2005)

\section{Methods}

Since in south-eastern Australia Aboriginal people were soon displaced from their traditional lands and confined to reserves (Christie 1979), records of plant use often

Paper from the Australian Systematic Botany Society Conference held in Darwin, September 2007 
rely on European sources such as nineteenth century books (Smyth 1876), (Dawson 1881), (Curr 1886), and unpublished documents. Exact identification of species is sometimes difficult, but Smyth contains several lists of plants identified by Mueller. Knowledge of plant use still remains in Aboriginal communities and has been freely given (Mason unpublished, and many others). It has been possible to compile extensive Filemaker Pro databases of species for which there are records, written or oral. (Gott unpublished). These cover, separately, Victoria, New South Wales, Tasmania and the higher rainfall areas of South Australia and contain plants used for food, medicines, fibre, implements, adhesives and cultural purposes. Table 1 shows the number of species with recorded Indigenous use for the above purposes in New South Wales. Totalling all databases, there are 513 records covering approximately 1511 species. Copies are held by the Australian National Botanical Gardens, the Australian Institute of Aboriginal and Torres Strait Islander Studies, Canberra, and other organizations and individuals. This present paper deals with only a few examples of the utilised species or genera contained in the databases. For further details on the use of plants in Victoria see Gott (1993).

Table 1. Number of NSW plant species with recorded Indigenous use. From Gott (unpublished) NSWUSE database. Note that many species had more than one use.

$\begin{array}{lllllll}\text { Food } & \text { Medicine } & \text { Fibre } & \text { Implement } & \text { Adhesive } & \begin{array}{l}\text { Other(incl. } \\ \text { cultural uses) }\end{array} & \text { Total } \\ 1248 & 496 & 159 & 260 & 103 & 260 & 1479\end{array}$

\section{Food Plants - "roots"}

Despite a popular view of hunting as the major food source, foods of vegetable origin were important in the diet (Gott 1982) and were always the fallback foods, gathered mainly by women and children.

In the higher rainfall areas of southeastern Australia, plant underground storage organs - "roots" in the broad sense - constituted the staple foods. The advantage of "roots" as staples is that they were available virtually year-round. William Buckley, the so-called 'wild white man' was a convict who escaped from the abortive settlement at Sullivan's Bay near Sorrento, Victoria, in 1803 and lived with the Wathaurong tribe around Geelong until 1834 (Morgan 1852). Throughout his account of life with the Wathaurong he constantly refers to 'roots' as the staple food, and this is borne out by many later observers.

' their natural food consists of the meat of the country when they can kill it, but chiefly roots' (T. Winter 1837 in Bride 1898).

'They depend for food almost entirely on animals and roots' (Dawson 1881)

The main sources of 'root' staples were small herbaceous perennials - geophytes that relied on underground storage to survive the dry hot summers, and some aquatics (Table 2). In the lower rainfall areas of south-eastern Australia and in the arid centre, seeds were more important as staples (Fig.1). Most of the species store carbohydrate in the roots as starch with amylose and amylopectin in varying proportions. However, some common Liliaceae sens.lat. (Arthropodium, Bulbine, Caesia, Thysanotus species) 


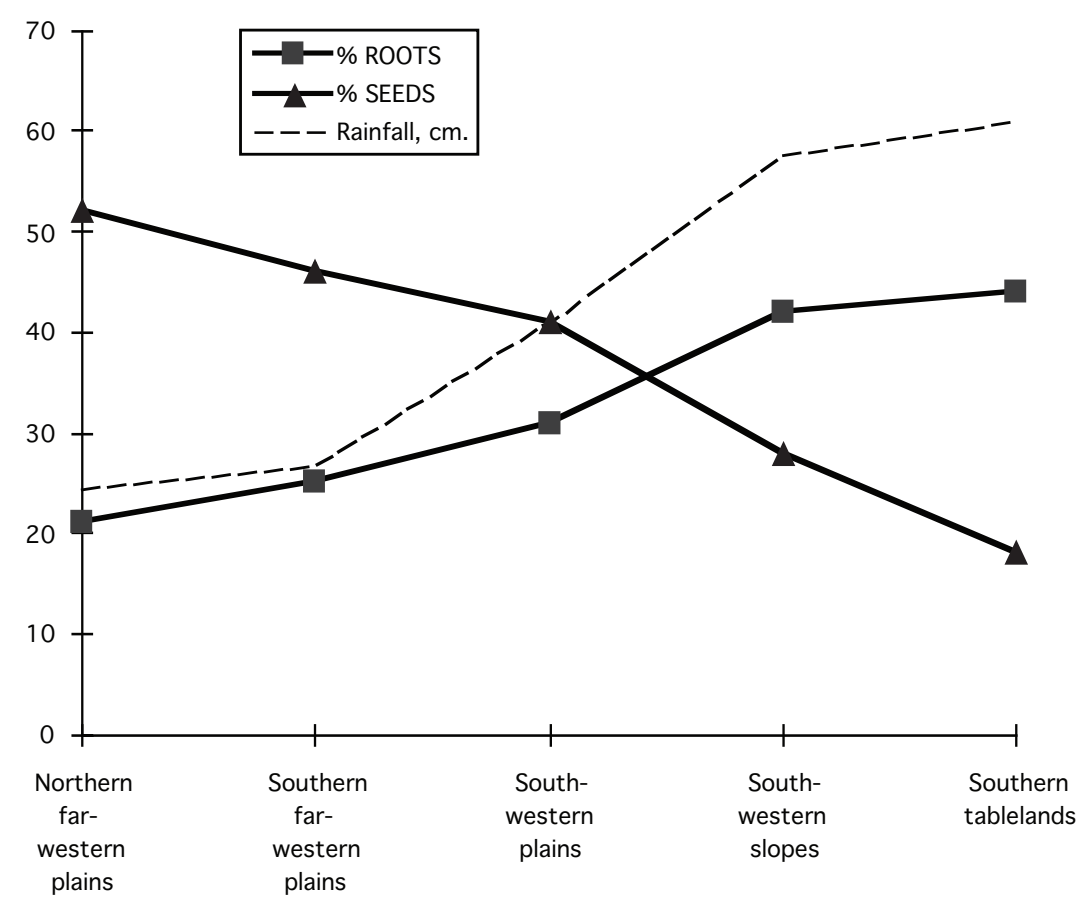

Fig. 1. Percentage of food plants providing roots and seeds from selected botanical divisions of New South Wales ( source - Gott B. NSWUSE database).

and the most frequently mentioned Victorian staples, Microseris lanceolata and M.scapigera, store fructans - polymers of fructose (Table 2.) (Incoll et al. 1989). The occurrence of large amounts of fructans in pre-European Aboriginal diets could have implications for the high susceptibility of Aborigines to develop type 2 diabetes on European diets, which for them were exclusively starch-based (O'Dea 1986), (Englyst \& Hudson 1997).

Of the several Arthropodium species, the most impressive is the informally named 'Arthropodium species A' (Conran et al. 1993) (='Arthropodium species 1' of Conran 1994), found in alpine areas of New South Wales and Victoria. The tubers, which persist for more than a year, are particularly large and numerous (Fig. 2) and would have been available to tribes who frequented the high country in summer to feast on Bogong Moths, Agrotis infusa Boisduval. This Arthropodium species flowered spectacularly after the recent 2002-03 fires in the Kosciuszko National Park (New South Wales).

Although individual orchid species are rarely mentioned in historical records, orchid tubers as a general class were recorded as food; indeed they are still eaten in Europe (Kunkel 1984). The starch in orchid tubers is high in amylopectins, which would contribute to a relatively high Glycaemic Index. Some starch-containing roots such as Pteridium esculentum (G.Forst.)Cockayne and Geranium species would have been processed to break up the fibre content. 
Table 2. Some food plants used for their "roots"

Family

Anthericaceae

Asphodelaceae

Asteraceae

Colchicaceae

Colchicaceae

Cyperaceae

Dennstaedtiaceae

Geraniaceaez

Hypoxidaceae

Juncaginaceae

Orchidaceae

Phormiaceae

Typhaceae
Species

Arthropodium spp.

Bulbine spp.

Microseris lanceolata

Burchardia umbellata

Wurmbea spp.

Bolboschoenus spp.

Pteridium esculentum

Geranium spp.

Hypoxis spp.

Triglochin procerum sl

All species

Caesia spp.

Typha spp.

\section{Storage Carbohydrate}

fructans

fructans

fructan (inulin)

starch

starch

starch

starch

starch

starch

starch

starch, high amylopectins

fructans

starch

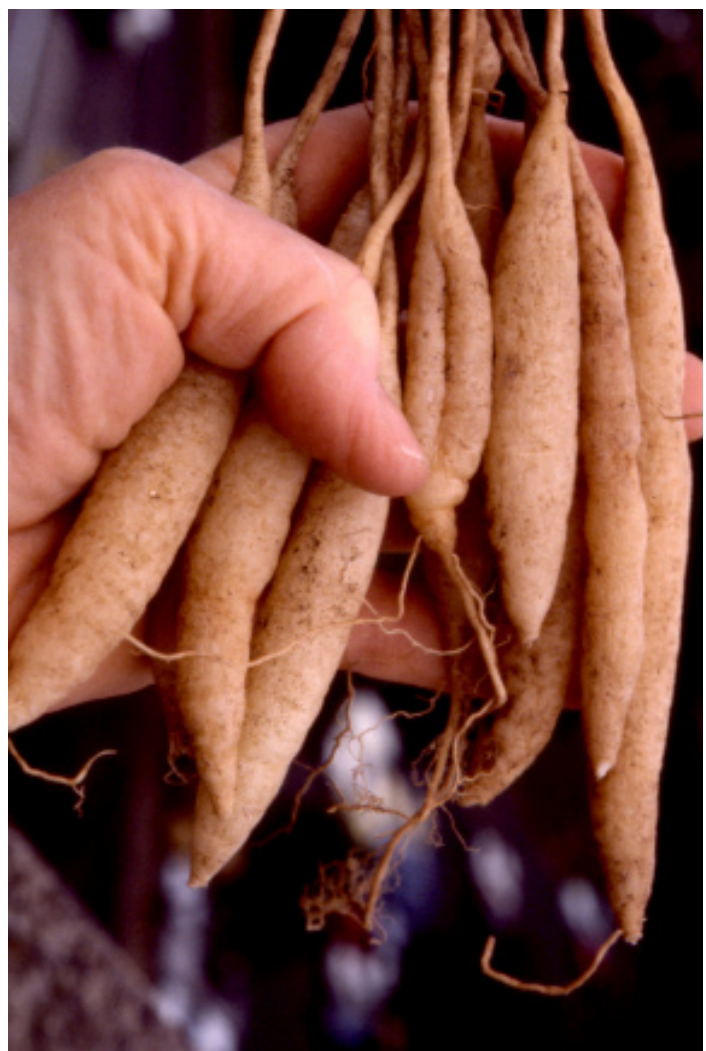

Fig. 2. Tubers of Arthropodium sp. A (Conran et al. 1993)/sp. 1 (Conran 1994). 


\section{Aquatic Species}

Typha domingensis Pers.and T.orientalis C.Presl were used widely for food and fibre along the Murray-Darling system and in the Victorian Gippsland Lakes (Gott 1999). The stele of the rhizome is packed with starch and has strong fibrous vascular bundles that were used for string. On the lower Murray River Charles French Angas remarked: 'The staff of their existence is the bulrush root...it is to them what bread is to the European' (Angas 1847).

Triglochin procera R.Br. and related species have numerous soft root tubers that descend from the rhizome and are able to survive prolonged drought. They were an important food along the Murray River (Beveridge 1889), and were probably eaten all over Australia (Levitt 1982, Specht 1958). The hard corms of Bolboschoenus species were eaten after beating between stones. Young shoots and rhizomes of Phragmites australis Trin.ex Steud. were eaten by the Tasmanians (Peron F 1802 in Plomley 1983). The stems were most important for spears and necklaces, and well-grown material was traded down from the Murray River to southern Victoria.

\section{Food plants - fruits and seeds}

Fruits and seeds are seasonal only (Table 3), but were sometimes stored. Harvesting them would often result in big meetings with neighbouring tribes. An example of this is Kunzea pomifera F.Muell. (Fig. 3) which bears clusters of fragrant small pome-like fruits on the sandy coasts of western Victoria and South Australia (Dawson 1881). Along the Coorong the fruit was pounded into large cakes and traded to other tribes (Tindale 1981). It is at present becoming popular in the bushfood industry.

Nitraria billardieri DC. was another very popular fruit (Beveridge 1889) (Fig. 4) especially along the Murray River. It was notable around cooking mounds, presumably growing from discarded 'stones'. Rubus parvifolius L., R.rosifolius Sm., Sambucus gaudichaudiana DC., S. australasica (Lindl.) Fritsch and several Solanum species were widely eaten. Solanum vescum F.Muell. was greatly relished in Gippsland, Victoria (Mueller 1855). It can be managed as a fireweed, abundant after fire and disappearing after a few years only to re-appear with the next fire from the soil seed store.

Table 3. Some fruits and seeds used for food

$\begin{array}{ll}\text { Species } & \text { Used for } \\ \text { Acacia, selected spp. } & \text { seed ground, also eaten green } \\ \text { Eragrostis spp. } & \text { seed ground } \\ \text { Kunzea pomifera } & \text { fruit } \\ \text { Macrozamia communis } & \text { seed detoxified } \\ \text { Marsilea drummondii } & \text { sporocarp processed } \\ \text { Nitraria billardieri } & \text { fruit } \\ \text { Panicum spp. } & \text { seed ground } \\ \text { Portulaca oleracea } & \text { seed ground, stored } \\ \text { Rubus spp. } & \text { fruit } \\ \text { Sambucus spp. } & \text { fruit } \\ \text { Solanum vescum } & \text { fruit }\end{array}$




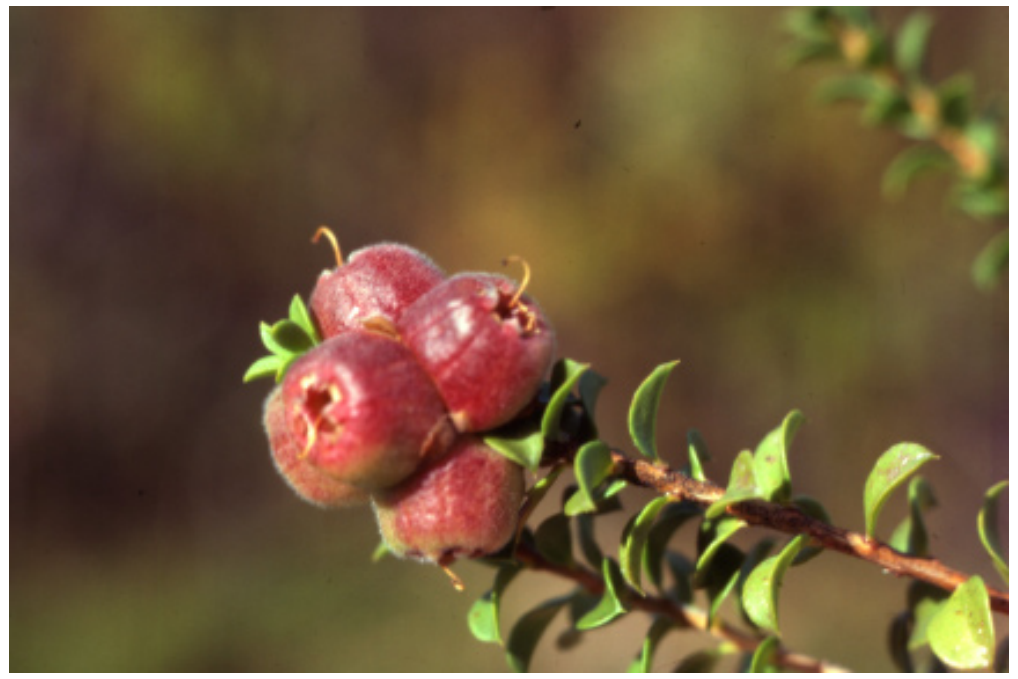

Fig. 3. Kunzea pomifera fruits

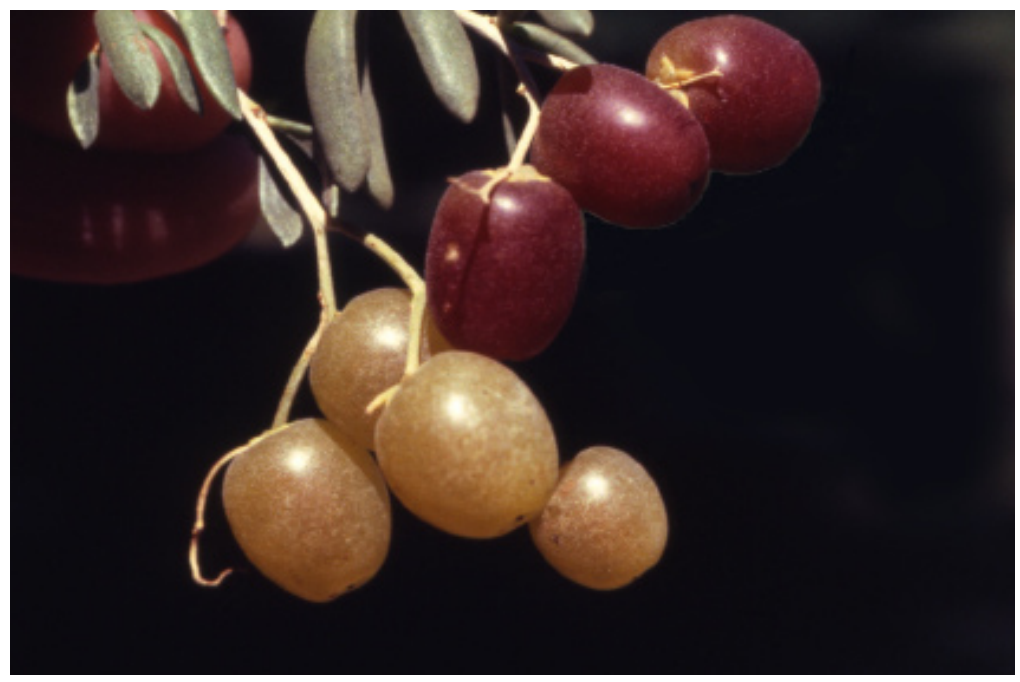

Fig. 4. Nitraria billarderi fruit (both the dark and the light fruits are ripe). 
In the drier areas, seeds of grasses were ground for flour, particularly Eragrostis and Panicum species. Seed of selected Acacia species was used; the lipid content of both the seed and the aril vary widely between species (O’Dowd \& Gill 1986). Portulaca oleracea L. seed was stored for future use (Smyth 1878). Macrozamia communis L.Johnson seed required processing to remove toxins (Backhouse 1836). Nardoo, Marsilea drummondii A.Braun, is well known as the last food resource used by the explorers Burke and Wills before their deaths in July 1861 while on the Victorian Exploring Expedition. Less well known is that it contains an enzyme which destroys thiamine and may well have contributed to their deaths (McCleary \& Chick 1977). For Aborigines it was only a fallback food, and was winnowed to remove the hard spore cases.

Other foods were "greens" from small herbs, nectar from flowers, gum from some Acacias and plant sap from lerp and manna. No sources of plant food were ignored, although some were resorted to only when more preferred foods were scarce. Table 4 lists some plants with uses other than food.

Table 4. Other plant uses.

Species
Acacia dealbata/A.mearnsii
Amyema sp.
Carex tereticaulis
Centipeda spp.
Duboisia hopwoodii
Eucalyptus camaldulensis
Eucalyptus spp.
Gynatrix pulchella
Lomandra longifolia
Mentha australis
Pimelea microcephala
Pimelea spp.
Xanthorrhoea spp.

Species

\author{
Use \\ Fibre - bark \\ Medicine - steam bath \\ Fibre - stem \\ Medicine \\ Medicine \\ Artefact - canoes \\ Medicine - kino \\ Fibre - outer stem \\ Fibre - leaf \\ Medicine \\ Medicine - acupressure \\ Fibre - outer stem \\ Adhesive - resin
}

\section{Medicine Plants}

Records of medicinal plants in south-eastern Australia are less frequent than those from the northern Australian areas, where much traditional knowledge has been preserved (Low 1990, Aboriginal Communities of the Northern Territory 1993). Nevertheless, some northern species also occur in the south-east. Aromatic plants such as Mentha spp. (Lamiaceae) and Centipeda spp. (Asteraceae) species were widely used medicinally, often against the imported European diseases. Materials with high tannin content, such as Eucalypt kino (sap), were used on burns and wounds. The modern use of transdermal nicotine patches is mirrored by the placing behind the ear of chewed 
wads of Pituri, Duboisia hopwoodii (F.Muell.) F.Muell., a widely traded source of nornicotine (Watson 1983). Indeed aromatherapy with Acacia flowers (Plomley 1966), acupressure with string from Pimelea microcephala R.Br. (Koch 1898), steam baths with Amyema species (Stone 1911) and the application of medicines in smoke and as body-washes show that Aboriginal medicinal use of plants was varied and welldeveloped.

\section{Fibre Plants}

Fibre was used from a wide variety of species. Coarse string was made from the inner bark of large Acacia species and stringybark Eucalypts. Typha species were valued for the stelar fibres equally with their use for starchy food. Fine string to make the nets for catching Bogong Moths was prepared from Pimelea axiflora F.Muell.ex Meisn. and/ or P.pauciflora R.Br. (Helms 1895). Fine coiled baskets continue to be made from the strong stems of Carex tereticaulis F.Muell. and baskets, string and eel traps came from leaves of Lomandra longifolia Labill. Buckets were made from whole bark pieces of Acacia dealbata Link and A. mearnsii De Wild.

\section{Adhesives}

A widely used adhesive was the waterproof resin from the leaf bases of Xanthorrhoea species. It was gently melted and mixed with fine fibrous material to make it less brittle.

\section{Implements}

Wooden implements such as boomerangs, spears, clubs, shields, digging sticks and containers are well represented in Museum collections. From ethnographic accounts and by direct microscopic sections it is sometimes possible to determine the species concerned (Smyth 1876, Kamminga 1988).

\section{Microseris}

Microseris lanceolata (Walp.) Sch. Bip., and M. scapigera (Forst.) Sch.Bip., Murnong or Yam Daisy constituted the staple food most commonly mentioned in early records (Gott 1983), and were abundant in dry sclerophyll woodlands and grasslands. In 1839 Thomas Mitchell (1839) reported the view over the plains of western Victoria as 'quite yellow with its flowers' and G.A. Robinson, in north-central Victoria in 1840, referred to 'millions of murnong or yam all over the plain' (Robinson in Clark 1998). Belonging to the Asteraceae, tribe Lactuceae, its leaves form a rosette, beginning growth in autumn from a stem-base to which are attached one or more soft tubers. New tubers form by the swelling of adventitious roots arising from the axils of the lower leaves. This applies to the 'Murnong' ecotype - see Table 5. For a discussion of the anatomy of the tubers see Gott 1983. At present it is proposed that there are two species, M.lanceolata and M.scapigera (Sneddon pers. comm. in Vijverberg et al. 2002). 
Table 5. Microseris ecotypes - after Vijverberg et al. (2002) (No species from Western Australia were included in the study.)

\begin{tabular}{|c|c|c|c|c|}
\hline Ecotype & Roots & Pappus & Fertilisation & Distribution \\
\hline Murnong,M & $\begin{array}{l}\text { short to long soft tubers } \\
\text { from adventitious roots }\end{array}$ & scale & non selfing & VIC, NSW, SA \\
\hline Alpine, A & $\begin{array}{l}\text { long }+ \text { /- tuberous } \\
\text { adventitious roots } \\
\text { producing new rosettes }\end{array}$ & scale & non selfing & VIC, NSW \\
\hline Fine pappus $F$ & $\begin{array}{l}\text { Long fibrous }+/ \text { - tuberous } \\
\text { roots }\end{array}$ & fine & selfing & VIC, TAS, NZ \\
\hline Coastal C & fibrous & narrow scale & selfing & NZ \\
\hline
\end{tabular}

The introduction by Europeans of hard-hoofed, close-grazing animals disastrously reduced the abundance of Microseris. Within 5 years of the founding of Melbourne it had disappeared from the surrounding area (Dredge1839-1843). Curr, writing of the northern Victorian plains in the 1840's said: 'Several thousand sheep not only learnt to root up these vegetables with their noses, but they for the most part lived on them for the first year, after which the root began gradually to get scarce' (Curr 1886:240). The result today is that the occurrence of this genus is highly fragmented.

\section{Genetics of Microseris}

Recent work has suggested that Australian and New Zealand Microseris originated from western North America "An allotetraploid $(4 x=36)$ which arose through hybridisation between an annual and a perennial diploid, followed by polyploidisation and long distance dispersal" (Prober et al.1998) and has undergone adaptive radiation in Australia and New Zealand.

On the basis of genetic studies using chloroplast DNA, and detailed morphological studies, Vijverberg et al. (2002), have described four ecotypes: Murnong, Alpine, Fine pappus, and Coastal (Table 5). Vijverberg et al. conclude that 'the morphological diversification is accompanied by little genetic variation (Vijverberg et al.1999, 2000). 'The taxon is in a relatively early stage of adaptive radiation' and that the 'process of adaptive radiation and morphological differentiation is progressing. They further state that the genetics indicate that 'an unambiguous classification of Australian and New Zealand Microseris is complicated at this early stage of adaptive radiation.

Indicative of this situation is that M. lanceolata in Flora of Victoria has been split into three informal species (Jeanes 1999).

It must be borne in mind that the populations of the various ecotypes have been long affected by human intervention. This particularly applies to the Murnong ecotype. Its tubers are non-fibrous, and at a shallow depth. As a preferred food for the Aborigines, it was subject to patch burning in late summer at intervals of approximately $3-5$ years. This burning, both in dry sclerophyll woodlands and grasslands, ensured the maintenance of open sites for the growth of all the herbaceous perennial food plants (Gott 2005). Microseris and other food plants were also spread widely by trading (Morgan 1852). 
The advent of European burning and grazing decimated and fragmented the populations of all the ecotypes, reducing the possibility of genetic interchange. Prober et al. (1998) found that, while isolated populations still retained allele richness, small populations were undergoing gradual genetic decline.

\section{Microseris pollen}

Pollen of the Lactuceae is distinct from other Asteraceae, and there are relatively few native species (c.10) that belong to the Lactuceae, including Microseris (Table 6). Lactuceae pollen appears in southern Australia during the upper Miocene (McPhail 1999). The possibility of tracing the evolutionary history of Microseris by distinguishing its pollen from other Lactuceae has been investigated but did not show promise (G. Crowley, L.Head, B.Gott, unpublished).

Table 6. Members of the Tribe Lactuceae native to South-eastern Australia

Actites megalocarpa

Cratystylis conocephala

Microseris lanceolata/scapigera

Picris, 3 spp.
Taraxacum, 2spp

Sonchus hydrophilus

Sonchus oleraceus

Youngia japonica

\section{A final word}

Aboriginal people have interacted with the Australian flora for many thousands of years. It is well to bear in mind that the evolutionary history of many of the species used by them may reflect that interaction.

\section{Acknowledgments}

My thanks to Barry Conn for many helpful comments on the first draft of this paper.

\section{References}

Aboriginal Communities of the Northern Territory (1993) Traditional Aboriginal Medicines. (Conservation Commission of the Northern Territory: Darwin)

Angas GF (1847) Savage Life and Scenes in Australia and New Zealand. (Smith Elder: London)

Backhouse J (1836) An enumeration of plants noticed on visits to Moreton Bay and Lake Macquarie in 1836. Australian Joint Copying Project MS: Microfilm roll 596.

Beveridge P (1889) The Aborigines of Victoria and Riverina. (Hutchinson: Melbourne)

Bride TF (1898) Letters from Victorian Pioneers, 1983 edition. (Currey O’Neil: Melbourne)

Christie MF (1979) Aborigines in Colonial Victoria 1835-86. (Sydney University Press)

Clark ID (1998) The Journals of George Augustus Robinson' Vol.1. (Heritage Matters: Melbourne)

Conran JG, McCune S, \& Hardin DW (1993) Arthropodium. Pp. 94-95 in Harden JG (ed.) Flora of New South Wales, vol. 4. (New South Wales University Press: Kensington)

Conran JG (1994) Arthropodium. Pp. 658-662 in Walsh NG \& Entwisle TJ (eds) Flora of Victoria, vol. 2. (Inkata Press: Melbourne)

Curr EM (1886) The Australian race (Government Printer: Melbourne) 
Dawson J (1881) Australian Aborigines, Facsimile1981. (Australian Institute of Aboriginal Studies: Canberra)

Dredge J (1839-43) Diary. State Library of Victoria MSS 16-2, 16-3. (Melbourne)

Edwards, R. 1972 Aboriginal bark canoes of the Murray valley. (Rigby: Adelaide)

Englyst HN \& Hudson GJ (1997) Starch and Health. Pp. 9-21in Frazier PJ, Richmond P \& Donald AM (eds) Starch, Structure and Functionality. Special Publication No.205. (Royal Society of Chemistry: Cambridge)

Gott B (1982) Ecology of root use by the Aborigines of southern Australia. Archaeology in Oceania 17: 59-67.

Gott B (1983) Murnong - Microseris scapigera: a study of a staple food of Victorian Aborigines. Australian Aboriginal Studies 1983: 2-17.

Gott B (1993) Use of Victorian Plants by Koories. Pp. 195-211 in Foreman DB \& Walsh NG (eds.) Flora of Victoria, vol.1 (Inkata Press: Melbourne)

Gott B (1999) Cumbungi, Typha species, a staple Aboriginal food in southern Australia. Australian Aboriginal Studies 1999(1): 33-50.

Gott B (2005) Aboriginal Fire Management in South-eastern Australia: aims and frequency. Journal of Biogeography 32:1203-1208.

Gott B (unpublished) NSWUSE database, The Use of New South Wales Plant Species by Aborigines (viewed November 2007) Filemaker Pro database, custodian Beth Gott.

Gott B (unpublished) SAUSE database, The Use of South Australian Plant Species by Aborigines (viewed November 2007) Filemaker Pro database, custodian Beth Gott.

Gott B (unpublished) TASUSE database, The Use of Tasmanian Plant Species by Aborigines (viewed November 2007) Filemaker Pro database, custodian Beth Gott.

Gott B (unpublished) VICUSE database, The Use of Victorian Plant Species by Aborigines (viewed November 2007) Filemaker Pro database, custodian Beth Gott.

Helms R (1895) Anthropological notes. Proceedings of the Linnean Society of New South Wales ser.2. 20:387-408.

Incoll LD, Bonnett GD \& Gott B (1989) Fructans in the underground storage organs of some Australian plants used for food by Aborigines. Journal of Plant Physiology 134:196-202.

Jeanes JA (1999) Asteraceae - Microseris. Pp.701-2 in Foreman DB \& Walsh NG (eds) Flora of Victoria, vol.4 (Inkata Press: Melbourne).

Kamminga J (1988) Wood artefacts: a checklist of plant species utilised by the Australian Aborigines. Australian Aboriginal Studies 1988 (2): 26-59.

Koch M (1898) A list of plants collected on Mt.Lyndhurst run, S. Australia. Transactions of the Royal Society of South Australia 22: 109-110.

Kunkel G (1984) Plants for Human Consumption. (Koeltz, Koenigstein: Germany).

Levitt D (1981) Plants and People. (Australian Institute of Aboriginal Studies Canberra)

Low T (1990) Bush Medicine. (Angus \& Robertson: Australia)

Macphail MK (1999) Palynostratigraphy of the Murray Basin, inland south-eastern Australia. Palynology 23:197-240.

Mason R (unpublished) List of traditional plant use, south-eastern New South Wales.

McCleary BV \& Chick BV (1977) The purification and properties of a Thiaminase 1 enzyme from Nardoo (Marsilea drummondii). Phytochemistry 16: 207-213.

Mitchell TL (1839) Three Expeditions into the Interior of Eastern Australia. (T \& W Boone: London)

Morgan J (1852) The life and adventures of William Buckley,1980 reprint. (ANU Press: Canberra)

Mueller F (1855) Account of the Gunyang: a new indigenous fruit of Victoria. Transactions and Proceedings of the Victorian Institute for the Advancement of Science 1854-5.

O'Dea, K (1986) The modern western diet as the exception in man's history. Sport Health 4: $8-12$.

O’Dowd D \& Gill AM (1986) Seed dispersal syndromes in Australian Acacia. Pp. 87-121 in Murray D (ed.) Seed Dispersal. (Academic Press: New York) 
Plomley NJB (1966) Friendly Mission. (Tasmanian Historical Research Association: Hobart)

Plomley NJB (1983) The Baudin Expedition and the Tasmanian Aborigines 1802. (Blubber Head Press: Hobart)

Prober SM, Spindler LH \& Brown ADH (1998) Conservation of the Grassy White Box Woodlands: effects of remnant population size on genetic diversity in the allotetraploid herb Microseris lanceolata. Conservation Biology 12(6): 1279-1290.

Smyth RB (1876) Aborigines of Victoria. (Government Printer: Melbourne)

Specht RL (1958) The American-Australian Scientific Expedition to Arnhem Land, vol.3: 483. (Melbourne University Press)

Stone AC (1911) The Aborigines of Lake Boga, Victoria. Proceedings of the Royal Society of Victoria 23: 433-468.

Tindale NB (1981) Desert Aborigines and the southern coastal peoples: some comparisons. Pp.1855-1883 in Keast A (ed.) Ecological Biogeography of Australia. (Junk: Boston)

Vijverberg K, Mes THM, \& Bachmann K (1999) Chloroplast DNA evidence for the evolution of Microseris in Australia and New Zealand after long-distance dispersal from western North America. American Journal of Botany 86(10):1448-1463.

Vijverberg K, Kuperus P, Breeuwer JAJ \& Bachmann K (2000) Incipient adaptive radiationof New Zealand and Australian Microseris (Asteraceae): an amplified fragment length polymorphism (AFLP) study. Journal of Evolution and Biology 13: 997-1008.

Vijverberg K, Lie L \& Bachmann K (2002) Morphological, evolutionary and taxonomic aspects of Australian and New Zealand Microseris (Asteraceae). Australian Journal of Botany 50: 127-143.

Watson P (1983) This precious foliage. Oceania monograph No.26, (Sydney University)

Manuscript received 03 December 2007, accepted 30 June 2008 